\title{
Teachers as Designers of Technology Enhanced Learning
}

Citation for published version (APA):

Kali, Y., McKenney, S., \& Sagy, O. (2015). Teachers as Designers of Technology Enhanced Learning. Instructional Science, 43(2), 173-179. https://doi.org/10.1007/s11251-014-9343-4

DOI:

$10.1007 / \mathrm{s} 11251-014-9343-4$

Document status and date:

Published: 01/03/2015

Document Version:

Early version, also known as pre-print

Document license:

CC BY-SA

Please check the document version of this publication:

- A submitted manuscript is the version of the article upon submission and before peer-review. There can be important differences between the submitted version and the official published version of record. People interested in the research are advised to contact the author for the final version of the publication, or visit the DOI to the publisher's website.

- The final author version and the galley proof are versions of the publication after peer review.

- The final published version features the final layout of the paper including the volume, issue and page numbers.

Link to publication

\section{General rights}

Copyright and moral rights for the publications made accessible in the public portal are retained by the authors and/or other copyright owners and it is a condition of accessing publications that users recognise and abide by the legal requirements associated with these rights.

- Users may download and print one copy of any publication from the public portal for the purpose of private study or research.

- You may not further distribute the material or use it for any profit-making activity or commercial gain

- You may freely distribute the URL identifying the publication in the public portal.

If the publication is distributed under the terms of Article $25 \mathrm{fa}$ of the Dutch Copyright Act, indicated by the "Taverne" license above, please follow below link for the End User Agreement:

https://www.ou.nl/taverne-agreement

Take down policy

If you believe that this document breaches copyright please contact us at:

pure-support@ou.nl

providing details and we will investigate your claim.

Downloaded from https://research.ou.nl/ on date: 26 Apr. 2023 
This is a pre-print of:

Kali, Y., McKenney, S. \& Sagy, O. Teachers as designers of technology enhanced learning. Instructional Science 43(2), 173-179.

\title{
Teachers as Designers of Technology Enhanced Learning
}

Yael Kali, Susan McKenney \& Ornit Sagy

\begin{abstract}
While the benefits of teacher involvement in designing technology enhanced learning are acknowledged in the literature, far less is known about shaping that involvement to yield those benefits. Research is needed to understand how teachers learn through design; how teacher design activities may be supported; and how teacher involvement in design in various ways impacts the quality of the artifacts created, their implementation, and ultimately, student learning. Existing conceptual foundations for teacher design work are urgently in need of bolstering, and will definitely play a critical role in the future of instructional science. This special issue presents the work of a large collaborative group of researchers, which, since 2012, has explored divergence and convergence among multiple research projects involving Teachers as Designers of Technology Enhanced Learning (TaD of TEL), and has endeavored to extend existing knowledge to strengthen TaD of TEL as a field of research.
\end{abstract}

\section{Rationale}

For decades, scholarship on factors affecting curriculum implementation has pointed to the importance of involving teachers, to varying degrees, in shaping the learning scenarios in their own classrooms (Ben-Peretz, 1990). At the same time, recent technological developments have changed the nature of teacher design work. Today, teachers design, re-design, and customize not only analogue, but also technology enhanced learning materials and activities. Here, the term, 'design' is used broadly, to include the process of mapping and/or actually developing specific resources for teaching or learning. Three main areas of exploration characterize the limited but growing research base on Teachers as Designers of Technology Enhanced Learning (TaD of TEL). These areas are: the knowledge teachers have and/or need to engage in design; shaping teacher design trajectories given varied motives; and evidencebased considerations for supporting teacher designers.

TaD of TEL knowledge. Although teachers sometimes design in multi-professional expert teams (Kali, Markauskaite, Goodyear, Ward, 2011), teacher design work is often small scale and near-to-practice. It typically involves: (a) critical reflection on and redesign of one's personal practice, which teachers find insightful (Davis \& Varma, 2008); (b) evidence-based customization (Gerard, Spitulnik, \& Linn, 2010); and/or (c) team design within one organization (Voogt, Almekinders, van den Akker, \& Moonen, 2005). Teachers working in teams may take on various roles, such as re-designers of existing materials and activities, or co-designers creating completely new ones (Cviko, McKenney \& Voogt, 2014a; Penuel, Roschelle, \& Shechtman, 2007). Across the various modalities of teacher design work, individuals and teams require different types of knowledge to inform both the process and the products of design.

Motives for TaD of TEL. Teachers may choose to become involved in the design of technology enhanced learning for various reasons. First, the designed artifacts can provide resources tailored for use in specific classrooms with particular learners, which can improve student learning (Corcoran \& Siladner, 2009; Gerard, Varma, Corliss, \& Linn, 2011). Second, teachers often engage in design to achieve curriculum change (McKenney, 2005). Third, 
teacher involvement in the design of (innovative) products may be sought to increase their practicality (Könings, Brand-Gruwel, \& van Merriënboer, 2007). Fourth, teacher engagement in (technology enhanced learning) design can yield increased ownership and commitment for implementation (Carl, 2009; Cviko, McKenney, \& Voogt, 2014b). Finally, consistent with the notions of constructionism (Harel \& Papert, 1991), learning by design (Kolodner et al., 2003) and design mode (Bereiter \& Scardamalia, 2003), TaD of TEL can provide a rich, authentic and practical context for teacher learning about technology (Koehler \& Mishra, 2005) and for professional development; thus, increasing teachers' motivation to engage in this practice.

Supporting TaD of TEL. Research has shown that support can contribute greatly to both the processes and the products of TaD of TEL (Nihuka \& Voogt, 2012), especially when focused on how to structure work in teams, substantive vision, and process guidance. Analysis of design team conversations has shown that teachers stimulate each other to anticipate and solve practical challenges in early stages of design (Boschman, McKenney, \& Voogt, 2014). To establish and maintain the substantive focus for design, a shared vision is essential (De Koster, Kuiper, \& Volman, 2012). Conversations about vision and goals stimulate teachers to apply their (technological pedagogical content) knowledge, especially when tackling new topics (Kafyulilo, 2013). Research has demonstrated that high-quality process support is crucial for design success (Kali \& Ronen-Fuhrmann, 2011). Support can include: (collaborative) work planning; facilitating meetings; and/or structuring tasks through templates or pre-selected source materials (Huizinga, Handelzalts, Nieveen, \& Voogt, 2014).

\section{Approach}

Since 2012, the authors of this special issue have been working together to improve the quality and relevance of research related to TaD of TEL, and to strengthen it as a field of research. Starting at the International Conference of the Learning Sciences in 2012, working groups were formed to synthesize and extend existing knowledge related to various themes in the TaD of TEL field. For two years, the working groups continued their efforts to elaborate key themes in the domain, related to the main areas of exploration described above. One group focused on analyzing the work of teacher designers; this led to a contribution on the first area of exploration - knowledge teachers need and use for design (McKenney, Kali, Markauskaite, \& Voogt). Three groups focused on specific ways of shaping teacher design trajectories, given varied motives (second area of exploration) for engaging in TaD of TEL; this led to contributions on: developing ownership via participatory design (Cober, Tan, Slotta, So, \& Könings), teacher customizations to optimize student learning (Matuk, Linn, \& Eylon), and teacher learning by collaborative design (Voogt, Laferrière, Breuleux, Itow, Hickey, \& McKenney). Finally, one group focused on key characteristics of support (third area of exploration) for teacher designers (Svihla, Reeve, Sagy, \& Kali). Each thematic contribution, in relation to the three main areas of exploration, is shown in Figure 1. 


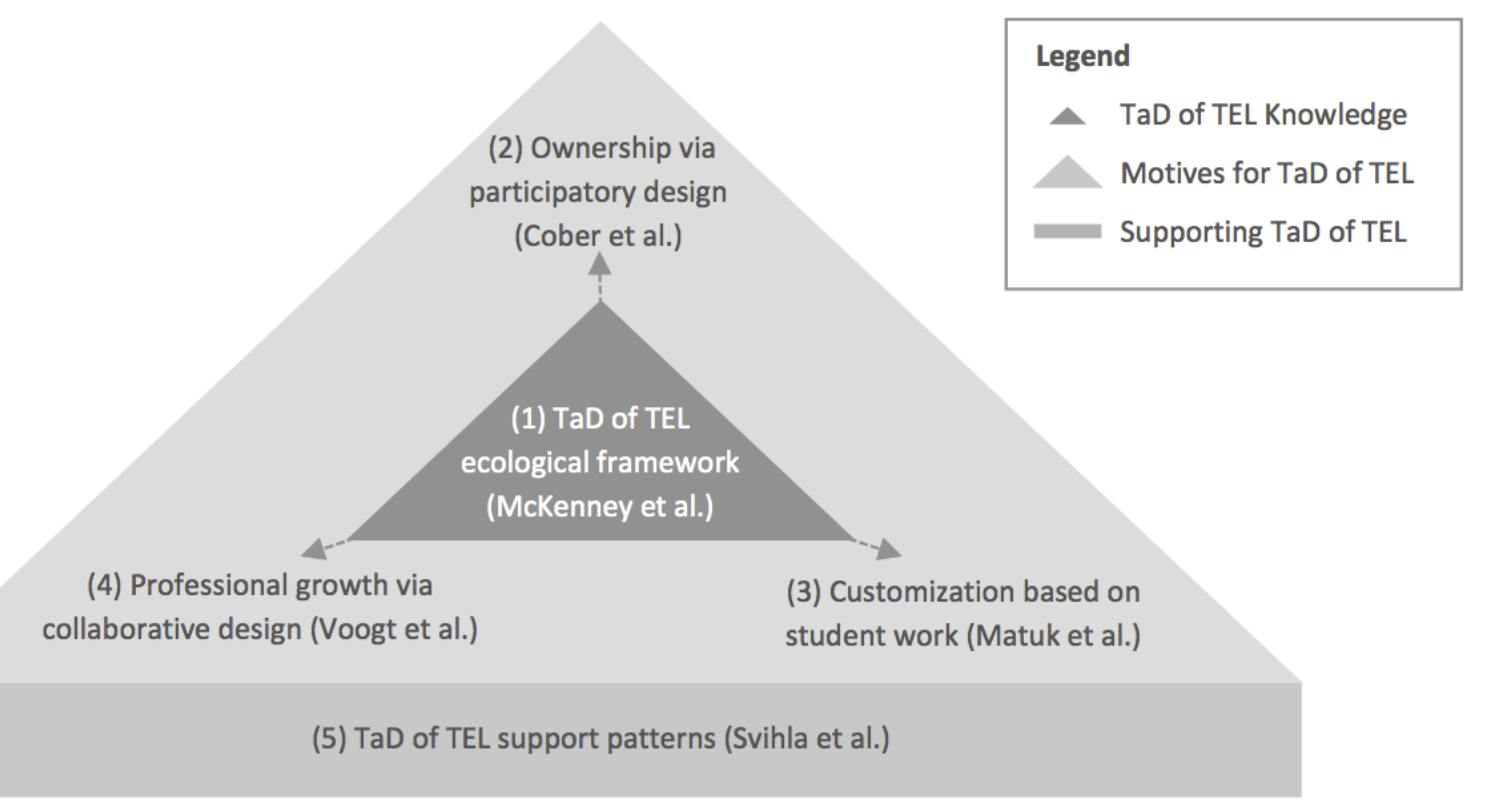

Figure 1: TaD of TEL areas of exploration

In 2014, the above-mentioned themes were further elaborated through discussions with the audience attending an invited session on this topic at the International Conference of the Learning Sciences (Voogt et al., 2014), as well as the excellent constructive comments provided by the anonymous reviewers for the current special issue. As this issue is released at about the same time as a related poster symposium at the annual meeting of the American Educational Research Association (Sagy, McKenney, \& Kali, forthcoming), we anticipate that the discussions will continue during, and after the conference. In so doing, we openly invite fellow researchers to join the effort to strengthen the TaD of TEL field of research. In addition to independent work, this could take place through sharing: constructive comments and criticism; responses to this special issue; or contributions for the growing library of resources available online at https://sites.google.com/site/teachersasteldesigners/.

\section{Overview of the special issue}

In accordance with the themes described above, this special issue includes six contributions. The first (McKenney et al.), synthesizes existing research on design and offers an ecological framework for assessing teacher assets and needs in designing technology enhanced learning. To do so, the synthesis draws on design related research ranging from design knowledge in general (e.g., Cross, 2011), to instructional design research (e.g., Ertmer et al., 2008, 2009), and $\mathrm{TaD}$ research (e.g., Davis, Beyer, Forbes, \& Stevens, 2011). The McKenney and colleagues' framework is termed 'ecological' because it emphasizes dependencies and interactions central to the design challenges tackled by teachers in the complex and dynamic settings in which they work. This contribution advances understanding related to the TaD of TEL knowledge area of research.

The second contribution (Cober et al.), studies different aspects of ownership that result from teachers' participation in design practices. This work builds on the participatory design approach as described in early works in a number of fields, including architecture, engineering, public health, and community development (Schuler \& Namioka, 1993). It also builds on the participatory design work presented in a previous special issue of Instructional Science (2014), and describes how this kind of thinking has been adopted by education 
researchers, to involve teachers and students in the design of educational innovations (e.g., Druin 2002; Könings, Brand-Gruwel, \& Van Merriënboer, 2011).

The third paper (Matuk, Linn, \& Eylon), contributes to a line of research (e.g., Remillard 1999, 2000; Grossman \& Thompson 2008), which explores the added value of teachers' re-design of given curriculum materials by making small, systematic adjustments. Specifically, Matuk and colleagues' contribution explains how teachers make customizations of web-based science inquiry projects in ways that take into account student learning with these projects. They also describe technological features that can support such customizations.

The fourth contribution (Voogt et al.), examines how participation in small design teams yields learning opportunities for teachers. Voogt and colleagues draw on the situative perspective articulated by Greeno and his colleagues (1998) and third-generation activity theory as developed by Engeström (1987) to describe and investigate teacher learning by collaborative design. Taken together, the second, third and fourth papers, advance understanding related to the motives for TaD of TEL area of research.

The fifth paper (Svihla et al.), contributes to the supporting TaD of TEL area of research by characterizing a 'fingerprint pattern' of supports in design courses, and offers guidelines for supporting teachers in the design of technology enhanced learning materials and activities. To develop this characterization, three case study teacher design courses were explored, that despite their differences in contextual aspects and pedagogical approach (e.g., project based learning as described by Brown and Campione, 1994, and the knowledge building communities model as described by Scardamalia, 2002), were found to have similar types of supports for teacher design.

Finally, the sixth contribution, by Kirschner, critically discusses issues that cut across each of the main themes. Taking the role of the devil's advocate, this discussion voices concerns from broader perspectives in educational research, notably (a) challenging the need for technology-specific considerations; and (b) stressing the ecology of education. Key issues receiving critical commentary include: importance of this work; feasibility and variation in existing research; and recommendations for future research.

\section{Significance of the special issue}

Increasingly, teaching is becoming viewed as a design profession, or even a design science, as put by Laurillard (2012): "Teaching is now a design science. Like other design professionals architects, engineers, programmers - teachers have to work out creative and evidence-based ways of improving what they do" (Laurillard, 2012 abstract). Today's use of technology in schools confronts teachers with additional design challenges. By synthesizing relevant literature and describing recent empirical investigations, this special issue provides clear and timely considerations for those aiming to investigate and/or facilitate teachers as designers of technology enhanced learning. The pathway to this special issue has initiated relevant conversations in person, in print, and online. With its publication and related resources, this special issue constitutes an important step in a much-needed direction to bolster the TAD of TEL field of research.

\section{References}

Ben-Peretz, M. (1990). The teacher-curriculum encounter. Albany: State University of New York Press. 
Bereiter, C., \& Scardamalia, M. (2003). Learning to work creatively with knowledge. Powerful learning environments: Unravelling basic components and dimensions, pp. 55-68. Oxford: Pregamon

Boschman, F., McKenney, S. \& Voogt, J. (2014). Understanding decision making in teachers' curriculum design approaches. Educational Technology Research and Development, 62, 393-416.

Brown, A. L., \& Campione, J. C. (1994). Guided discovery in a community of learners. Classroom lessons: Integrating cognitive theory and classroom practice, 229-270.

Carl, A. (2009). Teacher Empowerment Through Curriculum Development: Theory Into Practice (3rd ed.). Kenwyn, RSA: Juta.

Corcoran, T., \& Silander, M. (2009). Instruction in high schools: The evidence and the challenge. The Future of Children, 19(1), 157-183.

Cross, N. (2011). Design thinking: Understanding how designers think and work. New York: Berg.

Cviko, A,. McKenney, S., \& Voogt, J. (2014b). Teachers as co-designers of a technology-rich learning activities for emergent literacy. Technology, Pedagogy and Education, doi: 10.1080/1475939X.2014.953197.

Cviko, A., McKenney, S., \& Voogt, J. (2014a). Teacher roles in designing technology-rich learning activities for early literacy. Computers \& Education, 72, 68-79.

Davis, E. A., \& Varma, K. (2008). Supporting teachers in productive adaptation. In Y. Kali, M. C. Linn, M. Koppal \& J. E. Roseman (Eds.), Designing Coherent Science Education: Implications for curriculum, instruction, and policy (pp.94-122). N.Y.: Teachers College Press.

Davis, E. A., Beyer, C., Forbes, C. T., \& Stevens, S. (2011). Understanding pedagogical design capacity through teachers' narratives. Teaching and Teacher Education, 27(4), 797-810.

De Koster, S., Kuiper, E., \& Volman, M. (2012). Concept-guided development of ICT use in 'traditional' and 'innovative' primary schools: what types of ICT use do schools develop? Journal of Computer Assisted learning, 28(5), 454-464.

Druin, A. (2002). The role of children in the design of new technology. Behaviour and Information Technology, 21(1), 1-25.

Engeström, Y. (1987). Learning by expanding: An activity-theoretical approach to developmental research. Helsinki, Finland: Orienta-Konsultit.

Ertmer, P., D., Stepich, C., York, A., Stickman, X. Wu, S., Zurek, \& Y. Goktas. (2008). How instructional design experts use knowledge and experience to solve ill-structured problems. Performance Improvement Quarterly, 21, 17-42.

Ertmer, P., Stepich, D., Flanagan F., Kocaman-Karoglu A., Reiner C., Reyes L., Santone A., \& Ushigusa, S. (2009). Impact of guidance on the problem-solving efforts of instructional design novices. Performance Improvement Quarterly, 21, 117-132.

Gerard, L. F., Spitulnik, M., \& Linn, M. C. (2010). Teacher use of evidence to customize inquiry science instruction. Journal of Research in Science Teaching, 47(9), 10371063.

Gerard, L. F., Varma, K., Corliss, S. B., \& Linn, M. C. (2011). Professional development for technology-enhanced inquiry science. Review of Educational Research, 81(3), 408448.

Greeno, J. G., \& Middle School Mathematics through Applications Project Group. (1998). The situativity of knowing, learning, and research. American Psychologist, 53(1), 526.

Grossman, P., \& Thompson, C. (2008). Curriculum materials: Scaffolds for new teacher learning? Teaching and Teacher Education, 24, 2014-2026. 
Harel, I. E., \& Papert, S. E. (1991). Constructionism. Ablex Publishing.

Huizinga, T., Handelzalts, A., Nieveen, N., \& Voogt, J. (2014). Teacher involvement in curriculum design: Need for support to enhance teachers' design expertise. Journal of Curriculum Studies, 46, 1, 33-57.

Kafyulilo, A.C. (2013). Collaborative design in teams to develop science and mathematics teachers'technology integration knowledge and skills. Doctoral Thesis, University of Twente, Enschede.

Kali, Y., \& Ronen-Fuhrmann, T., (2011). Teaching to design educational technologies. The International Journal of Learning Technology (IJLT), 6(1), 4-23.

Kali, Y., Markauskaite, L., Goodyear, P., \& Ward, M-H. (2011). Bridging multiple expertise in collaborative design for technology-enhanced learning. Proceedings of the Computer Supported Collaborative Learning (CSCL) conference (pp. 831-835). ISLS.

Koehler, M., \& Mishra, P. (2005). What happens when teachers design educational technology? The development of technological pedagogical content knowledge. Journal of Educational Computing Research, 32(2), 131-152.

Kolodner, J. L., Camp, P. J., Crismond, D., Fasse, B., Gray, J., Holbrook, J., ... \& Ryan, M. (2003). Problem-based learning meets case-based reasoning in the middle-school science classroom: Putting learning by design (tm) into practice. The journal of the learning sciences, 12(4), 495-547.

Könings, K. D., Brand-Gruwel, S., \& van Merriënboer, J. J. G. (2007). Teachers' perspectives on innovations: Implications for educational design. Teaching and Teacher Education, 23(6), 985.

Könings, K. D., Brand-Gruwel, S., \& van Merriënboer, J. J. G. (2011). Participatory instructional redesign by students and teachers in secondary education: Effects on perceptions of instruction. Instructional Science, 39, 737-762.

Laurillard, D. (2012). Teaching as a design science: Building pedagogical patterns for learning and technology. London: Routledge.

McKenney, S. (2005). Technology for curriculum and teacher development: Software to help educators learn while designing teacher guides. Journal of Research on Technology in Education, 38(2) 167-190.

Nihuka, K. A., \& Voogt, J. (2012). Collaborative e-learning course design: Impacts on instructors. Australiasian Journal of Educational Technology, 28,2, 232-248.

Penuel, W., Roschelle, J., \& Shechtman, N. (2007). Designing formative assessment software with teachers: An analysis of the co-design process. Research and Practice in Technology Enhanced Learning, 2(1), 51-74.

Remillard, J. T. (1999). Curriculum materials in mathematics education reform: A framework for examining teachers' curriculum development. Curriculum Inquiry, 19(3), 315-342.

Remillard, J. T. (2005). Examining key concepts in research on teachers ... \& Robertshaw, M. B. (2007).Review of Educational Research, 75(2), 211-246.

Sagy, O., McKenney, S. \& Kali, Y. (forthcoming). Teachers as designers of technology enhanced learning. Symposium presentation at the annual meeting of the American Educational Research Association. April 16-20, Chicago.

Scardamalia, M. (2002). Collective cognitive responsibility for the advancement of knowledge. Liberal education in a knowledge society, 67-98.

Schuler, D., \& Namioka, A. (Eds.). (1993). Participatory design: Principles and practices. Hillsdale, NJ: Lawrence Erlbaum Associates, Inc.

Voogt, J., Almekinders, M., van den Akker, J., \& Moonen, B. (2005). A blended in-service arrangement for classroom technology integration: impacts on teachers and students. Computers in Human Behavior, 21(3), 523-539. 
Voogt, J., McKenney, S., \& Kali, Y., Breleux, A., Cober, R., Eylon, B-S., Itow, R., Könings, K., Laferrière, T., Linn, M. C., Markauskaite, L., Matuk, C., Reeve, R., Sagy, O., Slotta, J., So, H-J., Svihla, V., Tan, E., (2014). Teachers as designers. Presentation during an invited session. In Polman, J. L., Kyza, E. A., O'Neill, D. K., Tabak, I., Penuel, W. R., Jurow, A. S., O'Connor, K., Lee, T., and D'Amico, L. (Eds.). (2014). Learning and becoming in practice: The International Conference of the Learning Sciences (ICLS) 2014, Volume 1. Boulder, CO: International Society of the Learning Sciences (p. 14). 